\title{
Interatrial shunt devices for heart failure with normal ejection fraction: a technology update
}

This article was published in the following Dove Press journal:

Medical Devices: Evidence and Research

2 June 2017

Number of times this article has been viewed

\section{Joseph J Cuthbert \\ Pierpaolo Pellicori \\ Andrew L Clark}

Department of Cardiology, Hull York Medical School, Hull and East Yorkshire Medical Research and Teaching Centre, Castle Hill Hospital, Cottingham, Kingston upon Hull, UK
Correspondence: Joseph J Cuthbert Department of Cardiology, Hull York Medical School, Hull and East Yorkshire Medical Research and Teaching Centre, Castle Hill Hospital, Cottingham, Kingston upon Hull HUI6 5JQ, UK Tel +44 I482 46I 8I4

Email Joe.Cuthbert@hey.nhs.uk
Abstract: Heart failure with normal ejection fraction (HeFNEF) accounts for $\sim 50 \%$ of heart failure admissions. Its pathophysiology and diagnostic criteria are yet to be defined clearly which may hinder the search for effective treatments. The clinical hallmark of HeFNEF is exertional breathlessness, often due to an abnormal increase in left atrial pressure during exercise. Creation of an interatrial communication to offload the left atrium is a possible therapeutic approach. There are two percutaneously delivered devices currently under investigation which are discussed in this review.

Keywords: IASD, V-Wave, device therapy, HeFNEF, review, preserved EF, HeFPEF, HFpEF

\section{Introduction}

Heart failure with normal ejection fraction (HeFNEF) accounts for $\sim 50 \%$ of heart failure diagnoses, ${ }^{1,2}$ yet the underlying pathophysiology and diagnostic criteria are poorly defined. ${ }^{3-5}$ Partly as a consequence, no medical treatment has yet shown convincing outcome benefit for patients with HeFNEF. ${ }^{6-8}$ There is a clear unmet need for effective treatments for patients with HeFNEF. Implantable devices, such as cardiac resynchronisation therapy (CRT), improve symptoms and life expectancy in a subset of patients with heart failure and reduced ejection fraction (HeFREF). ${ }^{9}$ Some others allow early adjustment of medical therapy to avoid hospitalizations by monitoring cardiac haemodynamics. ${ }^{10}$ However, trials exploring the role of implantable devices such as CRT and rate-adaptive pacing in patients with HeFNEF have stalled, mainly due to recruitment failure, ${ }^{11-13}$ perhaps reflecting a reluctance of older patients with several comorbidities to participate.

The clinical hallmark of HeFNEF is exertional breathlessness, at least in part due to an abnormal increase in left atrial pressure (LAP) during exercise. ${ }^{14,15}$ In patients with severe pulmonary artery hypertension $(\mathrm{PAH})$, creation of a right to left atrial shunt reduces right atrial and ventricular pressures and improves symptoms, ${ }^{16-19}$ possibly due to increased systemic oxygen delivery due to increased cardiac output despite increasing cyanosis. ${ }^{20}$ Decompressing the left atrium might similarly provide symptomatic and haemodynamic improvement in patients with HeFNEF.

Reducing LAP with a percutaneously delivered atrial septal device is a novel potential therapeutic strategy. This review summarizes the potential clinical implications of reducing LAP with an interatrial shunt device in patients with $\mathrm{HeFNEF}^{21-23}$ and discusses the preliminary results of the clinical trials conducted so far. 


\section{Consequences of changing LAP}

There are many potential mechanisms leading to reduced exercise tolerance in patients with HeFNEF. ${ }^{14,24,25}$ In normal physiology, increased stroke volume during exercise is accomplished in part by the positive lusitropic consequence of sympathetic activation: left ventricular (LV) relaxation is enhanced with lower LV pressure in early diastole. ${ }^{26,27}$ Impaired LV relaxation and increased LV stiffness in patients with HeFNEF prevents an increase in end diastolic LV volume during exercise, ${ }^{28,29}$ thus increasing pressure in the left atrium. ${ }^{3}$ The excessive increase in LAP, measured by pulmonary capillary wedge pressure (PCWP), during exercise is a common finding in patients with $\mathrm{HeFNEF}^{14,15,29}$ and identifies those with a worse prognosis. ${ }^{30,31}$

Although patients with HeFNEF reach a lower peak workload (watts per kilogram of body weight) during incremental exercise tests compared with normal controls, both reach similar peak exercise PCWP. ${ }^{14}$ Increased workload-indexed peak exercise PCWP may be diagnostic of early-stage HeFNEF. ${ }^{14} \mathrm{~A}$ higher ratio of peak exercise PCWP to workload is associated with increased risk of 10-year mortality in patients with HeFNEF. ${ }^{31}$

Surgical and medical interventions that alter LAP might have a significant impact on symptoms and mortality in various cardiac pathologies. One example is that a device making invasive measurement of LAP as a guide for medical therapy in patients with HeFREF $(n=40)$ was associated with reduced LAP, improved symptoms, and reduced rates of worsening symptoms requiring intravenous diuretic therapy. ${ }^{32}$

In an observational study of 5 patients with high LAP and lower right atrial pressure (RAP) as a result of congenital obstructive left heart defects, the creation of an interatrial communication alleviated left atrial hypertension and improved symptoms. ${ }^{33}$ Conversely, pulmonary edema can develop in some patients secondary to dramatic increases in LAP following closure of an atrial septal defect (ASD). ${ }^{34,35}$

Two devices, the V-Wave ${ }^{\circledR}$ (V-Wave Ltd, Or Akiva, Israel) and IASD ${ }^{\circledR}$ (DC Devices Inc., Tewksbury, MA, USA) have been tested in patients with heart failure (Table 1).22,23,36-41

\section{V-Wave device}

The V-Wave device is a tri-leaflet porcine tissue valve on an hourglass-shaped nickel-titanium frame (Figure 1). ${ }^{36}$ The device is implanted via a femoral venous approach under general anesthetic with fluoroscopic and trans-esophageal echocardiography (TOE) guidance. ${ }^{22}$ Following radiofrequency trans-septal puncture, the center of the hourglass $(5 \mathrm{~mm}$ diameter) is placed across the fossa ovalis with the ends of the hourglass sitting in left and right atria securing the device in place. ${ }^{22}$ The left atrial orifice is lined with expanded polytetrafluoroethylene (ePTFE) designed to improve blood flow and restrict new tissue growth over the device. ${ }^{22}$ Blood flows from the left to right via the porcine valve which is designed to close when RAP exceeds $2 \mathrm{mmHg}$, thus preventing right to left shunting. ${ }^{22} \mathrm{After}$ device implantation, patients require anticoagulation with warfarin or direct-acting oral anticoagulant (DOAC) for 3 months and with low-dose aspirin indefinitely. ${ }^{22}$

A proof-of-principle study was conducted in a single center in Canada, in patients with heart failure and reduced ejection fraction. They had raised PCWP $(\geq 15 \mathrm{mmHg})$ without substantial right ventricular dysfunction $(n=10$; average age 62 years; average left ventricular ejection fraction (LVEF) 25\%; average PCWP $23 \mathrm{mmHg}$; and average NTproBNP $2712 \mathrm{pg} / \mathrm{mL}) \cdot{ }^{36}$ After 3 months, insertion of the device was associated with a reduction in New York Heart Association (NYHA) class, increased 6-minute walk test distance, and improved quality of life (QoL) and physical function assessed by Kansas City cardiomyopathy questionnaire and Duke activity status index. ${ }^{36}$ Device implantation was associated with a modest decrease in LV volumes and PCWP $(23 \mathrm{mmHg}$ pre-procedure to $17 \mathrm{mmHg}$ at 3 months; $p=0.035$ ); however, natriuretic peptides (NPs), RAP ( 9 vs $8 \mathrm{mmHg}$ at 3 months; $p=0.18$ ), and mean pulmonary artery pressure ( 29 vs 26 mmHg at 3 months, $p=0.37$ ) were unchanged. ${ }^{36}$

A preliminary case report demonstrated the feasibility and safety of the $\mathrm{V}$-Wave device in a patient severely symptomatic with HeFNEF and a history of ischemic heart disease and atrial fibrillation (AF) (PCWP $22 \mathrm{mmHg}$, LVEF 50\%, taking $240 \mathrm{mg}$ of furosemide per day). ${ }^{39}$ Device insertion was associated with improved symptoms (NYHA III at baseline vs II at 6 months), functional capacity (6-minute walk test distance $281 \mathrm{~m}$ at baseline vs $617 \mathrm{~m}$ at 6 months), and a substantial drop in NTproBNP $(2983 \mathrm{pg} / \mathrm{mL}$ at baseline vs $1334 \mathrm{pg} / \mathrm{mL}$ at 6 months). ${ }^{39}$

A further prospective, nonrandomized, open label, multicenter study of the device is planned in patients with both HeFREF and HeFNEF (NCT02511912) (Table 2). ${ }^{42}$

\section{IASD device}

The interatrial shunt device (IASD) differs from the V-Wave device in three ways: first, the device does not incorporate valve tissue; second, the inter-atrial communication is larger ( 8 $\mathrm{mm}$ diameter compared with $5 \mathrm{~mm}$ with the $\mathrm{V}$-Wave device); third, the device is a bare metal and not coated with ePTFE. Instead, the left atrial side of the device is flush with the atrial tissue to reduce the risk of thrombus formation (Figure 2) ${ }^{23}$ 
Table I Summary of trials of interatrial shunt devices

\begin{tabular}{|c|c|c|c|c|c|c|}
\hline Trial & Device & Study design & $\mathbf{n}$ & Inclusion/exclusion criteria & Patient characteristics & Results \\
\hline Del Trigo et al ${ }^{36}$ & V-Wave ${ }^{\circledR}$ & $\begin{array}{l}\text { Prospective } \\
\text { Single-arm } \\
\text { Nonrandomized } \\
\text { Un-blinded }\end{array}$ & 10 & $\begin{array}{l}\text { Inclusion } \\
\text { - } \geq 18 \text { years of age } \\
\text { - } \geq 6 \text { month history of HF } \\
\text { - NYHA III or IV } \\
\text { - On optimal medical and device } \\
\text { therapy } \\
\text { - LVEF } \leq 40 \% \\
\text { - Severe RVSD } \\
\text { - PCWP } \geq 15 \mathrm{mmHg} \\
\text { Exclusion } \\
\text { - Cerebrovascular or } \\
\text { thromboembolic event in the } \\
\text { last } 6 \text { months } \\
\text { - Coagulation disorders or } \\
\text { contraindications for oral } \\
\text { anticoagulation } \\
\text { - Left atrial or ventricular } \\
\text { thrombus } \\
\text { - PASP }>70 \text { mmHg }\end{array}$ & $\begin{array}{l}\text { Average age: } 62 \text { years } \\
\text { Average LVEF: } 25 \% \\
\text { Average PCWP: } \\
23 \mathrm{mmHg} \\
\text { Average NTproBNP: } \\
2712 \mathrm{pg} / \mathrm{mL}\end{array}$ & $\begin{array}{l}\text { - No serious adverse device } \\
\text { events after } 3 \text { months } \\
\text { - Reduction in NYHA class, } \\
\text { increased } 6 \mathrm{MWT} \text { distance, } \\
\text { improved QoL and physical } \\
\text { functional status after } 3 \\
\text { months } \\
\text { - Reduction in mean PCWP } \\
\text { ( } 23-17 \mathrm{mmHg} \text { ) after } 3 \\
\text { months ( } p=0.035) \\
\text { - NTproBNP unchanged from } \\
\text { baseline to } 3 \text { months }\end{array}$ \\
\hline $\begin{array}{l}\text { Sondergaard } \\
\text { et } \mathrm{al}^{23} \\
\text { Malek } \\
\text { et } \mathrm{al}^{37}-1 \text {-year } \\
\text { follow-up }\end{array}$ & IASD $^{\circledR}$ & $\begin{array}{l}\text { Prospective. } \\
\text { Single-arm. } \\
\text { Nonrandomised. } \\
\text { Un-blinded. }\end{array}$ & 11 & $\begin{array}{l}\text { Inclusion } \\
\text { - } \geq \text { I HF hospitalisation in the } \\
\text { last year or persistent NYHA } \\
\text { class III or IV symptoms for } \\
3 \text { months. } \\
\text { - } \geq 40 \text { years of age } \\
\text { - LVEF } \geq 45 \% \\
\text { - Dilated LA indexed for body } \\
\text { size without more than mild } \\
\text { mitral valve disease } \\
\text { - PCWP } \geq 15 \text { mmHg at rest or } \\
\geq 25 \text { mmHg during exercise. } \\
\text { - HR } \leq 90 \text { bpm if in AF } \\
\text { - On stable medical therapy: on } \\
\text { diuretics for } \geq 2 \text { months and } \\
\text { no changes to cardiovascular } \\
\text { medications in } \leq 2 \text { weeks prior } \\
\text { to enrolment. } \\
\text { Exclusion } \\
\text { - Prior history of } \\
\text { cerebrovascular or } \\
\text { thromboembolic events } \\
\text { - Left atrial thrombus } \\
\text { - Valve disease worse than mild } \\
\text { - Significant LV wall motion } \\
\text { abnormalities } \\
\text { - RVSD } \\
\text { - Estimated PASP }>60 \text { mmHg } \\
\text { - Restrictive or obstructive lung } \\
\text { disease worse than mild. } \\
\text { - }>70 \% \text { coronary artery stenosis } \\
\text { untreated or ACS within } \\
3 \text { months of enrolment. } \\
\text { - Contraindications to dual } \\
\text { antiplatelet therapy or oral } \\
\text { anticoagulation }\end{array}$ & $\begin{array}{l}\text { Average age: } 7 \text { I years } \\
\text { Average LVEF: } 57 \% \\
\text { Average PCWP: } \\
19 \mathrm{mmHG} \\
\text { Median NTproBNP: } \\
148 \mathrm{pg} / \mathrm{mL}\end{array}$ & $\begin{array}{l}\text { - No serious adverse device } \\
\text { events after } 30 \text { days } \\
\text { - One hospitalization with } \\
\text { worsening HF after } 30 \text { days } \\
\text { - } 28 \% \text { reduction in mean } \\
\text { PCWP after } 30 \text { days } \\
\text { ( } p=0.005) \\
\text { - NYHA, 6MWT, and QoL } \\
\text { assessment improvements } \\
\text { after } 30 \text { days follow-up } \\
\text { - Improvement in NYHA class } \\
\text { sustained after I year but } \\
\text { improvements in 6MWT and } \\
\text { QoL assessment were no } \\
\text { longer statistically significant } \\
\text { - No change in NTproBNP at } \\
\text { any time point }\end{array}$ \\
\hline
\end{tabular}


Table I (Contined)

\begin{tabular}{|c|c|c|c|c|c|c|}
\hline Trial & Device & Study design & $\mathbf{n}$ & Inclusion/exclusion criteria & Patient characteristics & Results \\
\hline $\begin{array}{l}\text { REDUCE } \\
\text { LAP-HF }{ }^{38,40,41}\end{array}$ & IASD & $\begin{array}{l}\text { Prospective. } \\
\text { Single-arm. } \\
\text { Multi-centre. } \\
\text { Open-label. } \\
\text { Nonrandomised. } \\
\text { Un-blinded. }\end{array}$ & 68 & $\begin{array}{l}\text { Inclusion } \\
\text { - } \geq 40 \text { years of age } \\
\text { - NYHA III or IV and/or } \\
\text { I HF hospitalisation and/ } \\
\text { or treatment with guideline } \\
\text { directed therapies within } \\
\text { I } 2 \text { months of enrolment } \\
\text { - LVEF } \geq 40 \% \\
\text { - Mean PCWP } \geq 15 \text { mmHg at } \\
\text { rest or } \geq 25 \text { mmHg during } \\
\text { exercise. } \\
\text { Exclusion } \\
\text { - ACS within } 3 \text { months of } \\
\text { enrolment } \\
\text { - CRT within } 6 \text { months of } \\
\text { enrolment } \\
\text { - Severe HF } \\
\text { - Cerebrovascular or } \\
\text { thromboembolic event within } \\
6 \text { months of enrolment } \\
\text { - Significant valvular disease } \\
\text { - RVSD } \\
\text { - AF with resting HR }>100 \text { bpm } \\
\text { - Intracardiac vegetation, mass } \\
\text { or thrombus } \\
\text { - Systolic BP }>\text { I } 70 \text { mm Hg }\end{array}$ & $\begin{array}{l}\text { Average age: } 69 \text { years } \\
\text { Average LVEF: } 47 \% \\
\text { Average PCWP: } \\
17 \mathrm{mmHg} \\
\text { Median NTproBNP: } \\
377 \mathrm{pg} / \mathrm{mL}\end{array}$ & 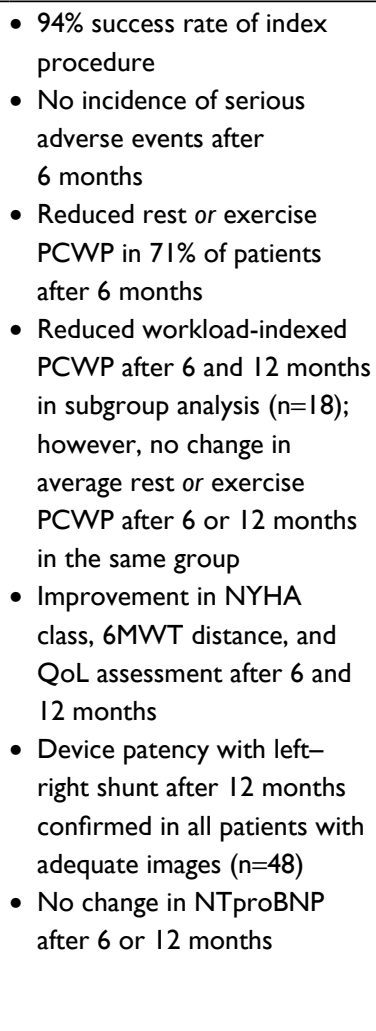 \\
\hline
\end{tabular}

Abbreviations: HF, heart failure; NYHA, New York Heart Association; LVEF, left ventricular ejection fraction; RVSD, right ventricular systolic dysfunction; PCWP, pulmonary capillary wedge pressure; PASP, pulmonary artery systolic pressure; NTproBNP, N-terminal B-type natriuretic peptide; 6MWT, 6-minute walk test; QoL, quality of life; LA, left atrium; HR, heart rate; AF, atrial fibrillation; LV, left ventricle; ACS, acute coronary syndrome; CRT, cardiac resynchroniozation therapy; eGFR, estimate glomerular filtration rate; $\mathrm{BP}$, blood pressure.

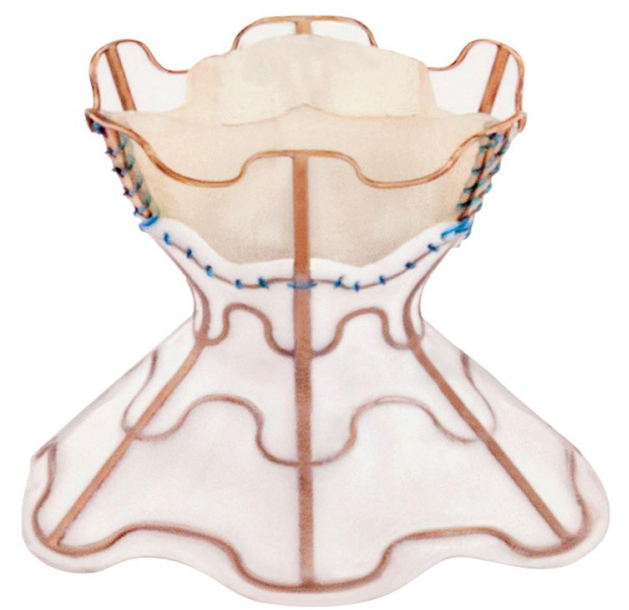

Figure I The V-Wave ${ }^{\circledR}$ interatrial shunt device.

Note: Reprinted from Lancet, 387, Del Trigo M, Bergeron S, Bernier M, et al, Unidirectional left-to-right interatrial shunting for treatment of patients with heart failure with reduced ejection fraction: a safety and proof-of-principle cohort study, 1290-1297, Copyright (2016), with permission from Elsevier. ${ }^{36}$

The first in man experience of IASD was a nonrandomized, unblinded, feasibility study in patients with HeFNEF and baseline PCWP $\geq 15 \mathrm{mmHg}$ at rest or $\geq 25 \mathrm{mmHg}$ during exercise $(n=11$, average age 71 years; average LVEF 57\%; median NTproBNP $148 \mathrm{pg} / \mathrm{mL}$; average PCWP $19 \mathrm{mmHg}) .{ }^{23}$ Device implantation was associated with reduction in mean PCWP (by $28 \%$, from $19+5$ to $14+3 \mathrm{mmHg}, p=0.005$ ) after 30 days alongside symptomatic, functional, and QoL improvements. ${ }^{23}$ NTproBNP plasma levels did not significantly change. ${ }^{23}$ Devices were successfully implanted in all but one patient in whom device malpostion was corrected by the insertion of a new device. There were no reports of device-related complications such as migration or loss of patency (although in one patient the direction of flow could not be detected) after 30 days follow up. ${ }^{23}$ During the same period, one patient was admitted with acute heart failure. ${ }^{23}$ At 1 year, all patients survived and symptomatic improvement (measured by NYHA class) was sustained, although some patients required an increase in their daily dose of loop diuretics. ${ }^{37}$

\section{REDUCE LAP-HF trial}

The REDUCE LAP-HF trial was an open-label, nonrandomized phase 1 study of the IASD in patients with HeFNEF and raised PCWP ( $\geq 15 \mathrm{~mm}$ at rest or $\geq 25 \mathrm{mmHg}$ during exercise). ${ }^{38}$ A total of 68 patients were enrolled in 21 centers, with an average age of 69 years. Average LVEF was $47 \%$ and mean PCWP at rest was $17 \mathrm{mmHg}$; median NT-pro-BNP 
Table 2 Summary of future trials of interatrial shunt devices

\begin{tabular}{|c|c|c|c|c|c|}
\hline Trial & Device & Study design & $\begin{array}{l}\text { Estimated } \\
\text { enrollment }\end{array}$ & Inclusion/exclusion criteria & Outcome measures \\
\hline RELIEVE-HF ${ }^{42}$ & V-Wave ${ }^{\circledR}$ & $\begin{array}{l}\text { Prospective } \\
\text { Single-arm } \\
\text { Multicenter } \\
\text { Nonrandomized } \\
\text { Unblinded }\end{array}$ & 60 & $\begin{array}{l}\text { Inclusion: } \\
\text { - NYHA III or IV taking optimal medical } \\
\text { therapy } \\
\text { - } \text { LVEF } \geq 15 \% \\
\text { Exclusion: } \\
\text { - RVSD } \\
\text { - RAP > LAP } \\
\text { - Congenital heart disease } \\
\text { - Severe pulmonary hypertension } \\
\text { - Severe restrictive or obstructive lung } \\
\text { disease }\end{array}$ & $\begin{array}{l}\text { - Device-related MACCE within } \\
6 \text { months of device implantation } \\
\text { - Changes in 6MWT after } 6 \text { months } \\
\text { - Overall MACCE after } 12 \text { months }\end{array}$ \\
\hline $\begin{array}{l}\text { REDUCE } \\
\text { LAP-HFREF }^{68}\end{array}$ & IASD $^{\circledast}$ & $\begin{array}{l}\text { Prospective } \\
\text { Single-arm } \\
\text { Nonrandomized } \\
\text { Un-blinded }\end{array}$ & 10 & $\begin{array}{l}\text { Inclusion: } \\
\text { - NYHA III or IV and signs of pulmonary } \\
\text { congestion (rales, chest } X \text {-ray findings) } \\
\text { and } \geq I \text { HF hospitalization in last } \\
\text { I2 months } \\
\text { - Stable optimal medical, device, and } \\
\text { surgical therapy for } 6 \text { months } \\
\text { - } \geq 18 \text { years of age } \\
\text { - LVEF } 20 \%-40 \% \text { on echocardiography } \\
\text { - Resting PCWP } \geq 18 \mathrm{mmHg} \text { and PCWP } \\
\text { greater than RAP by } \geq 5 \text { mmHg } \\
\text { Exclusion: } \\
\text { - NTproBNP }<100 \text { pmol/L in SR or } \\
<300 \text { pmol/L in AF } \\
\text { - MI, PCl, or CABG in previous } 3 \text { months } \\
\text { - ICD or CRT in previous } 3 \text { months } \\
\text { - Severe HF } \\
\text { - } 6 M W T>600 \text { m } \\
\text { - Cerebrovascular or thromboembolic } \\
\text { disease }<6 \text { months } \\
\text { - Significant valve disease } \\
\text { - Contraindication to dual antiplatelet or } \\
\text { anticoagulant therapy } \\
\text { - AF with HR }>100 \text { bpm } \\
\text { - Resting RAP }>14 \text { mmHg } \\
\text { - RVSD } \\
\text { - Systolic BP }>170 \mathrm{mmHg}\end{array}$ & $\begin{array}{l}\text { - Peri-procedural and 6-month } \\
\text { MACCE and systemic embolic } \\
\text { events } \\
\text { - Percentage of patients who have } \\
\text { successful device implantation } \\
\text { during index procedure } \\
\text { - Percentage of patients with left- } \\
\text { right flow through the device }\end{array}$ \\
\hline
\end{tabular}

Abbreviations: NYHA, New York Heart Association; LVEF, left ventricular ejection fraction; RVSD, right ventricular systolic dysfunction; RAP, right atrial pressure; LAP, left atrial pressure; MACCE, major adverse cardiac and cerebrovascular events; 6MWT, 6-minute walk test; HF, heart failure; PCWP, pulmonary capillary wedge pressure; NTproBNP, N-terminal B-type natriuretic peptide; SR, sinus rhythm; AF, atrial fibrillation; MI, myocardial infarction; PCl, percutaneous coronary intervention; CABG, coronary artery bypass graft; ICD, implantable cardio-defibrilator; CRT, cardiac resynchroniozation therapy; HR, heart rate; BP, blood pressure.

was $377 \mathrm{pg} / \mathrm{mL}$ (interquartile range 222-925 pg/mL). ${ }^{40}$ The co-primary endpoints were the proportion of patients with successful device implantation, reduction in PCWP at rest and during exercise after 6 months, and evidence of a leftright shunt on echocardiography at the same time point. ${ }^{40}$

\section{Procedure and short-term safety outcomes}

Procedural complication rate was 5 in 66 initial procedures: 3 patients required removal of the initial device (misplacement $n=2$; suspected right atrial thrombus $n=1$ ). All the 3 patients subsequently underwent uncomplicated insertion of a second device. Two procedures had to be abandoned and were not repeated (one due to complications following trans-septal puncture and another due to unsuitable atrial anatomy). Overall, the device was successfully implanted in 64 patients $(94 \%){ }^{40}$

All the patients received dual antiplatelet therapy with aspirin and clopidogrel post procedure. In the first 6 months, there were no major adverse events, such as stroke, myocardial infarction, pulmonary or systemic embolism, or surgical intervention for device-related complications. ${ }^{40}$ Left to right blood flow through patent devices was confirmed at 6 months in all patients who had adequate images $(n=50) .{ }^{40}$ 


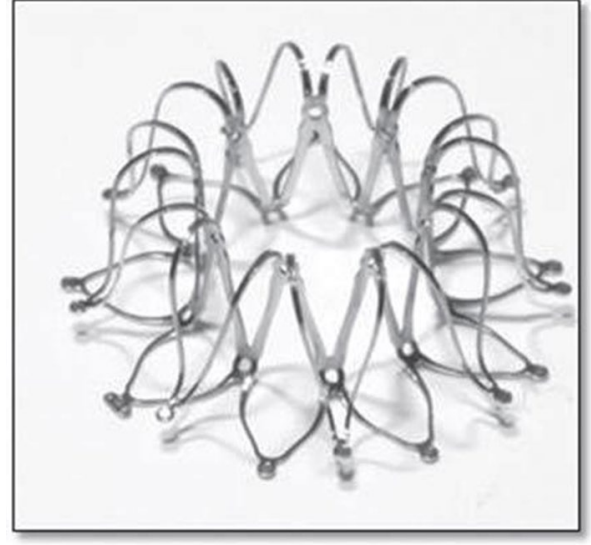

Figure 2 Expanded IASD ${ }^{\circledR}$ device.

Note: Copyright (C) 2014. John Wiley and Sons. Reproduce from Søndergaard L, Reddy V, Kaye D, et al. Transcatheter treatment of heart failure with preserved or mildly reduced ejection fraction using a novel interatrial implant to lower left atrial pressure. Eur J Heart Fail. 2014;16:796-801.23

\section{Hemodynamic outcomes}

After 6 months, IASD implantation was associated with reduced PCWP at rest in $52 \%$ of patients $(n=32)$ and reduced PCWP measured by right heart catheterization during supine bicycle exercise in $58 \%$ of patients $(n=34)$. The device was associated with reduced rest or exercise PCWP in $71 \%$ of patients $(\mathrm{n}=42)$ and reduced rest and exercise PCWP in 39\% of patients $(\mathrm{n}=23){ }^{40}$ However, hemodynamic testing in a subset of patients at 12 months $(\mathrm{n}=18)$ showed no difference in average rest or exercise PCWP or RAP between baseline, 6 months, and 12 months. ${ }^{41}$ Despite this, IASD insertion was associated with reduction in workload-indexed PCWP at peak exercise from baseline to 6 months $(p \leq 0.05)$ which was sustained at 12 months $(p \leq 0.01)$ (Figure 3$){ }^{41}$

\section{QoL and symptom outcomes}

Insertion of the IASD was associated with significant improvements in symptoms, QoL, and functional status

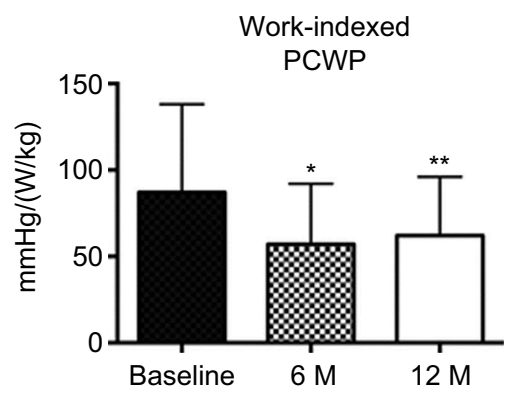

Figure 3 Bar graph showing workload-indexed peak exertion wedge pressure before and after interatrial shunt device placement $(n=16)$.

Notes: Data are mean \pm standard deviation. ${ }^{*} p<0.05, * * p<0.01$ versus baseline. Reproduced from Kaye DM, Hasenfuss G, Neuzil P, et al. One-year outcomes after transcatheter insertion of an interatrial shunt device for the management of heart failure with preserved ejection fraction. Circ Heart Fail. 2016;9(12):e003662. Available from http://circheartfailure.ahajournals.org/content/9//2/e003662.long. ${ }^{41}$ Abbreviations: PCWP, pulmonary capillary wedge pressure; M, months. at 6 months which were sustained at 12 month follow-up: NYHA class ( $p \leq 0.001$ at 6 and 12 months compared to baseline), QoL score ( $p \leq 0.001)$, and 6-minute walk distance $(p \leq 0.01)$ all improved (Figure 4$).^{41}$

\section{Long-term safety of IASD}

Of the 64 patients who had the device implanted, 3 patients (5\%) died between 6- and 12-month follow-up; 1 death was due to stroke, 1 due to pneumonia, and in 1 the cause was undetermined. ${ }^{41}$ There were 17 HF hospitalizations among 13 patients in the year post implantation, 10 of which occurred in 10 patients in the first 6 months. ${ }^{41}$ Left-right shunt through a patent device was confirmed on echocardiography at 12 months in all patients with good-quality images $(n=48) .{ }^{41}$

Introduction of a left-right atrial shunt with the IASD was associated with an increase in the right ventricular volume and ejection fraction, but not RAP compared to baseline. ${ }^{41}$ There was no effect on LVEF and left atrial volume, although LV diastolic volume decreased. ${ }^{41}$

Pulmonary artery oxygenation increased from $69 \%$ to $75 \%$ at 6 month follow-up $(p \leq 0.0001)$ confirming the presence of a left-right shunt, but was not reported at 12 months ${ }^{40,41}$ Although oximetry was used to measure LV output (which remained unchanged at 6 and 12 months), measures of systemic oxygenation were not reported at 6 or 12 months. ${ }^{40,41}$

\section{Limitations of REDUCE LAP-HF}

Creation of a left-right atrial shunt with either the V-Wave or IASD seems feasible and safe in the mid-term and may cause symptomatic improvement in some carefully selected patients with heart failure and raised LAP. However, caution is required when interpreting the available data.

- Around one third of the patients had $\mathrm{AF}^{40}{ }^{40}$ in which case PWCP might vary beat to beat. It is not clear whether one-off readings can be considered accurate or whether an average reading from a specific number of cardiac cycles was used instead.

- The change in PCWP (a designated primary outcome) was not significant unless indexed for a subjective, patientdependent variable such as exercise workload.

- The investigators reported a decrease in the difference between LAPs and RAPs (reduced PCWP-RAP gradient) which, in fact, would have meant an increased RAP/ PWCP ratio. ${ }^{40,41}$ Increased RAP/PCWP ratio is associated with poorer long-term outcome in hospitalized patients with advanced HeFREF (LVEF $<30 \%$ ), ${ }^{43}$ but the clinical importance of this in HeFNEF is not yet known. 
A

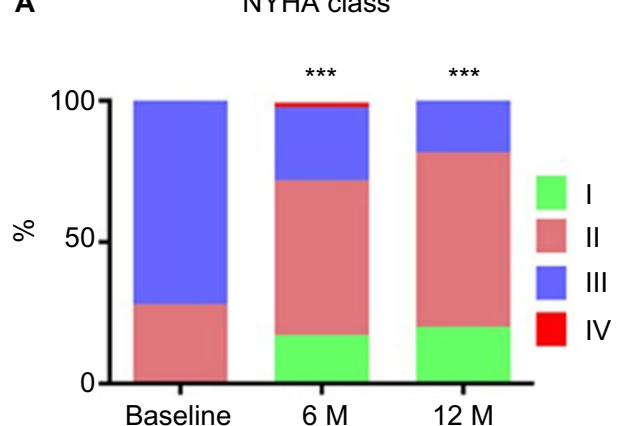

B
MLWHF score

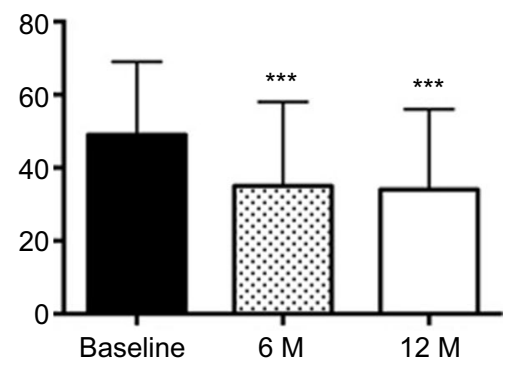

C

6MWD

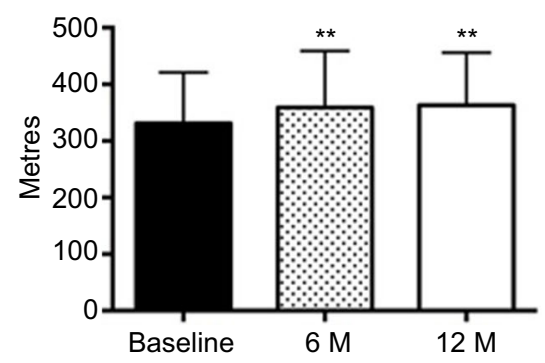

Figure 4 Bar graph represents the effects of interatrial septal shunt device implantation on (A) NYHA class ( $n=60)$; (B) MLWHF ( $=60)$; (C) 6MWD ( $n=55)$.

Notes: Data in B and C represent mean \pm standard deviation. ${ }^{* *} p<0.01$, ${ }^{* * *} p<0.001$ versus baseline. Reproduced from Kaye DM, Hasenfuss G, Neuzil P, et al. One-year outcomes after transcatheter insertion of an interatrial shunt device for the management of heart failure with preserved ejection fraction. Circ Heart Fail. 20 I6;9(I2):e03662. Available from http://circheartfailure.ahajournals.org/content/9//2/e003662.long. ${ }^{41}$

Abbreviations: NYHA, New York Heart Association; MLWHF, Minnesota Living with Heart Failure; 6MWD, 6-minute walk distance; M, months.

- Many of the other measured outcomes were obtained through subjective tests in nonrandomized and unblinded participants and investigators. Outcomes such as QoL score, exercise time, and workload are subject to bias. Inevitably, there must be at least some placebo effect from undergoing a novel procedure involving general anesthesia.

- Improvement in NYHA class was mirrored by an increase in average 6-minute walk distance $(331 \mathrm{~m}$ at baseline vs $363 \mathrm{~m}$ after 12 months, $p=0.001) .{ }^{41}$ However, interand intra-observer NYHA class ascriptions are variable with low validity and reproducibility. ${ }^{44,45}$ Therefore, an improvement in exercise distance of an average $32 \mathrm{~m}$ may not be compatible with an improvement in NYHA class and may be due, instead, to a learning effect intrinsic to the test. ${ }^{46}$

- HeFNEF was defined as the presence of symptoms and signs compatible with the diagnosis, a LVEF $>40 \%$, and PCWP $>15 \mathrm{mmHg}$ at rest or $>25 \mathrm{mmHg}$ during supine bicycle exercise on right heart catheterization. Although there are no universally accepted criteria to diagnose HeFNEF, some evidence suggests that there is no difference in resting and peak exercise PCWP between healthy controls, patients with hypertension, and patients with HeFNEF. $^{14,47}$
- There were no data on the average or median systolic blood pressure of the participants in REDUCE LAP-HF or, indeed, any trial of V-Wave or IASD. A reduction in LAP can be achieved with commonly used heart failure medications, such as angiotensin-converting enzyme inhibitors (ACEi) or beta-blockers. ${ }^{32}$ The use of diuretics, alone or in combination with an ACEi or angiotensin receptor blocker, improves symptoms and QoL in patients with HeFNEF.48 It cannot be known from the published data whether patients in whom the V-Wave or IASD was implanted were eligible for up-titration of their antihypertensive medications as an alternative means to reduce LAP, although $70 \%-90 \%$ were hypertensive. ${ }^{23,36,40}$ Indeed, 11 patients in REDUCE LAP-HF (17\%) required an increased dose of diuretics during 6-month follow-up. ${ }^{40}$

- The signs and symptoms of heart failure are notoriously nonspecific, and under-diagnosis and misdiagnosis of HeFNEF may be common. ${ }^{49-51}$ Serum NPs are the most powerful prognostic marker in $\mathrm{HeFNEF}^{52,53}$ and raised levels are a diagnostic requirement. ${ }^{54}$ However, raised serum NPs were not an inclusion criteria for REDUCE LAP-HF. ${ }^{38}$ Patients with HeFNEF and low NP levels probably have a good prognosis and thus are unlikely to benefit from invasive intervention. Of those with higher 
NTproBNP plasma levels, the proportion who had echocardiographic evidence to support the diagnosis of HeFNEF (raised E/E' ratio or augmented LV mass or left atrial volume), ${ }^{55}$ is not reported. Importantly, NP levels were not affected by device implantation. ${ }^{40,41}$

\section{Future perspective}

The long-term effects of the IASD are unknown. A chronic left-right shunt increases pulmonary blood flow and may be well tolerated at younger ages: patients with ASD are at increased risk of PAH and atrial arrhythmias, but clinical problems do not usually emerge until the fourth or fifth decade. ${ }^{56-65}$ However, in elderly individuals (the average age of patients in REDUCE LAP-HF was 69 years $)^{40}$ with HeFNEF and altered ventricular compliance, left-right atrial shunts may cause increased pulmonary arterial pressure and subsequent right ventricular dysfunction. Such hemodynamic changes might affect other organs already compromised in HeFNEF, such as the kidneys, ${ }^{3}$ with a subsequent negative impact on long-term outcome.

Another factor that may influence long-term outcome is the use of anticoagulation: IASD implantation required 1-year dual antiplatelet therapy, ${ }^{23}$ whereas V-Wave implantation required warfarin or DOAC for 3 months following implantation. ${ }^{22}$ Both the devices require indefinite, low-dose aspirin. ${ }^{22,23}$ A large proportion of patients with HeFNEF have $\mathrm{AF}$ and require anticoagulation anyway, ${ }^{3}$ which, in combination with aspirin, might increase bleeding risk. It is unclear whether, in patients with sinus rhythm, the anticoagulation required for either device is sufficient thrombo-prophylaxis or increases the risk of adverse events such as GI bleeding: one patient had a stroke during 12-month follow-up post IASD implantation, ${ }^{41}$ and one patient had a nonfatal gastrointestinal bleed during 3-month follow-up post V-Wave implantation. ${ }^{36}$ Vigilance and caution will be required with future trials.

Finally, changing patient behavior due to study involvement, known as the "Hawthorne effect,"66 may have influenced the results; possibly by increasing medication compliance during follow-up. In the absence of a control group with a sham procedure or blind readers, trials of V-Wave and IASD may be subject to the same bias that has been observed in trials of other invasive treatments, such as renal nerve denervation. ${ }^{67}$

\section{Conclusion}

HeFNEF remains an ill-defined clinical entity, which has lead, in part, to the failure to find effective treatment for the condition. Devices that can directly reduce LAP seem to be safe in the short- and mid-term, but there are no data on their long-term safety and efficacy.

Sham-controlled randomized trials would blind a patient to treatment, reducing the risk of bias which necessarily affects measures with a large subjective influence such as 6-minute walk distance or exercise workload. However, the practicalities may be difficult: the presence of a device would be easily spotted by an investigator during right heart catheterization or echocardiography. Careful selection of relevant endpoints (such as changes in symptoms) in patients blind to treatment (with a sham procedure) should be assessed by physicians also blinded to treatment.

Such a trial is essential to confirm that the benefits reported from unblinded studies are real. It is also unclear whether similar reductions in LAP sufficient to improve symptoms may be achievable with pharmacotherapy in patients with HeFNEF. Care must be taken with future trials (Table 2) to ensure that there is no bias leading to misinterpretation of efficacy.

\section{Disclosure}

The authors report no conflicts of interest in this work.

\section{References}

1. Yancy CW, Lopatin M, Stevenson LW, De Marco T, Fonarow GC; Committee ASA Investigators. Clinical presentation, management, and in-hospital outcomes of patients admitted with acute decompensated heart failure with preserved systolic function: a report from the Acute Decompensated Heart Failure National Registry (ADHERE) Database. J Am Coll Cardiol. 2006;47:76-84.

2. Fonarow GC, Stough WG, Abraham WT, et al. Characteristics, treatments, and outcomes of patients with preserved systolic function hospitalized for heart failure: a report from the OPTIMIZE-HF Registry. J Am Coll Cardiol. 2007;50:768-777.

3. Pellicori P, Cleland JG. Heart failure with preserved ejection fraction. Clin Med (Lond). 2014;14(Suppl 6):s22-s28.

4. Pellicori P, Cleland JG. Update on management of heart failure with preserved ejection fraction. Curr Opin Cardiol. 2015;30(2):173-178.

5. Ferrari R, Böhm M, Cleland JGF, et al. Heart failure with preserved ejection fraction: uncertainties and dilemmas. Eur J Heart Fail. 2015;17:665-671.

6. Patel K, Fonarow GC, Ekundayo OJ, et al. Beta-blockers in older patients with heart failure and preserved ejection fraction: class, dosage, and outcomes. Int J Cardiol. 2014;173(3):393-401.

7. Cleland JG, Tendera M, Adamus J, Freemantle N, Polonski L, Taylor $\mathrm{J}$; PEP-CHF Investigators. The perindopril in elderly people with chronic heart failure (PEP-CHF) study. Eur Heart J. 2006;27(19): 2338-2345.

8. Pitt B, Pfeffer MA, Assmann SF, et al. Spironolactone for heart failure with preserved ejection fraction. N Engl J Med. 2014;370(15):1383-1392.

9. Cleland JGF, Daubert JC, Erdmann E, et al. The effect of cardiac resynchronization on morbidity and mortality in heart failure. $N \mathrm{Engl}$ J Med. 2005;352:1539-1549.

10. Hutchinson K, Pellicori P, Dierckx R, Cleland JG, Clark AL. Remote telemonitoring for patients with heart failure: might monitoring pulmonary artery pressure become routine? Expert Rev Cardiovasc Ther. 2014;12(8):1025-1033. 
11. Linde C, Curtis AB, Fonarow GC, et al. Cardiac resynchronization therapy in chronic heart failure with moderately reduced left ventricular ejection fraction: Lessons from the Multicenter InSync Randomized Clinical Evaluation MIRACLE EF study. Int J Cardiol. 2016;202:349-355.

12. Kass DA, Kitzman DW, Alvarez GE. The restoration of chronotropic competence in heart failure patients with preserved ejection fraction (RESET) study: rationale and design. J Card Fail. 2010;16(1): 17-24.

13. US National Institutes of Health. ClinicalTrials.gov. Restoration of Chronotropic Competence in Heart Failure Patients with Normal Ejection Fraction (RESET). Available from: https:/clinicaltrials.gov/ct2/ show/NCT00670111. Accessed February 13, 2017.

14. Maeder MT, Thompson BR, Brunner-La Rocca HP, Kaye DM. Hemodynamic basis of exercise limitation in patients with heart failure and normal ejection fraction. J Am Coll Cardiol. 2010;56(11):855-863.

15. Borlaug BA, Nishimura RA, Sorajja P, Lam CS, Redfield MM. Exercise hemodynamics enhance diagnosis of early heart failure with preserved ejection fraction. Circ Heart Fail. 2010;3(5):588-595.

16. McLaughlin VV, Archer SL, Badesch DB, et al. ACCF/AHA 2009 expert consensus document on pulmonary hypertension: a report of the American College of Cardiology Foundation Task Force on Expert Consensus Documents and the American Heart Association developed in collaboration with the American College of Chest Physicians; American Thoracic Society, Inc. and the Pulmonary Hypertension Association. $J$ Am Coll Cardiol. 2009;53:1573-1619.

17. Keogh AM, Mayer E, Benza RL, et al. Interventional and surgical modalities of treatment in pulmonary hypertension. J Am Coll Cardiol. 2009;54(1 Suppl):S67-S77.

18. Sandoval J, Gaspar J, Peña H, et al. Effect of atrial septostomy on the survival of patients with severe pulmonary arterial hypertension. Eur Respir J. 2011;38:1343-1348.

19. Chiu JS, Zuckerman WA, Turner ME, et al. Balloon atrial septostomy in pulmonary arterial hypertension: effect on survival and associated outcomes. J Heart Lung Transplant. 2015;34:376-380.

20. Barst RJ. Role of atrial septostomy in the treatment of pulmonary vascular disease. Thorax. 2000;55(2):95-96.

21. Kaye D, Shah SJ, Borlaug BA, et al. Effects of an interatrial shunt on rest and exercise hemodynamics: results of a computer simulation in heart failure. J Card Fail. 2014;20(3):212-221.

22. Amat-Santos IJ, Bergeron S, Bernier M, et al. Left atrial decompression through unidirectional left-to-right interatrial shunt for the treatment of left heart failure: first-in-man experience with the V-Wave device. EuroIntervention. 2015;10(9):1127-1131.

23. Søndergaard L, Reddy V, Kaye D, et al. Transcatheter treatment of heart failure with preserved or mildly reduced ejection fraction using a novel interatrial implant to lower left atrial pressure. Eur J Heart Fail. 2014;16:796-801.

24. Haykowsky MJ, Brubaker PH, John JM, Stewart KP, Morgan TM, Kitzman DW. Determinants of exercise intolerance in elderly heart failure patients with preserved ejection fraction. $\mathrm{J} \mathrm{Am} \mathrm{Coll} \mathrm{Cardiol}$. 2011;58(3):265-274.

25. Abudiab MM, Redfield MM, Melenovsky V, et al. Cardiac output response to exercise in relation to metabolic demand in heart failure with preserved ejection fraction. Eur J Heart Fail. 2013;15: 776-785.

26. Cheng CP, Igarashi Y, Little WC. Mechanism of augmented rate of left ventricular filling during exercise. Circ Res. 1992;70(1):9-19.

27. Fukuta H, Little WC. The cardiac cycle and the physiological basis of left ventricular contraction, ejection, relaxation, and filling. Heart Fail Clin. 2008;4(1):1-11.

28. Borlaug BA, Jaber WA, Ommen SR, et al. Diastolic relaxation and compliance reserve during dynamic exercise in heart failure with preserved ejection fraction. Heart. 2011;97:964-969.

29. Zile MR, Baicu CF, Gaasch WH. Diastolic heart failure - abnormalities in active relaxation and passive stiffness of the left ventricle. $N$ Engl J Med. 2004;350:1953-1959.
30. Bourge RC, Abraham WT, Adamson PB, et al. Randomized controlled trial of an implantable continuous hemodynamic monitor in patients with advanced heart failure: the COMPASS-HF study. J Am Coll Cardiol. 2008;51:1073-1079.

31. Dorfs S, Zeh W, Hochholzer W, et al. Pulmonary capillary wedge pressure during exercise and long-term mortality in patients with suspected heart failure with preserved ejection fraction. Eur Heart J. 2014;35(44):3103-3112.

32. Ritzema J, Troughton R, Melton I, et al. Hemodynamically Guided Home Self-Therapy in Severe Heart Failure Patients (HOMEOSTASIS) Study Group. Physician-directed patient self-management of left atrial pressure in advanced chronic heart failure. Circulation. 2010;121:1086-1095.

33. Leonard Jr GT, Justino H, Carlson KM, et al. Atrial septal stent implant: atrial septal defect creation in the management of complex congenital heart defects in infants. Congenit Heart Dis. 2006;1:129-135.

34. Thomai F, Gaspardone A, Papa M, Polisca P. Acute left ventricular failure after transcatheter closure of a secundum atrial septal defect in a patient with coronary artery disease: a critical reappraisal. Catheter Cardiovasc Interv. 2002;55:97-99.

35. Masutani S, Senzaki H. Left ventricular function in adult patients with atrial septal defect: implication for development of heart failure after transcatheter closure. J Card Fail. 2011;17:957-963.

36. Del Trigo M, Bergeron S, Bernier M, et al. Unidirectional left-to-right interatrial shunting for treatment of patients with heart failure with reduced ejection fraction: a safety and proof-of-principle cohort study. Lancet. 2016;387:1290-1297.

37. Malek F, Neuzil P, Gustafsson F, et al. Clinical outcome of transcatheter treatment of heart failure with preserved or mildly reduced ejection fraction using a novel implant. Int J Cardiol. 2015;187:227-228.

38. Hasenfuss G, Gustafsson F, Kaye DM, et al. Rationale and design of the reduce elevated left atrial pressure in patients with heart failure (Reduce LAP-HF) trial. J Card Fail. 2015;21(7):594-600.

39. Amat-Santos IJ, Del Trigo M, Bergeron S, et al. Left atrial decompression using unidirectional left-to-right interatrial shunt: initial experience in treating symptomatic heart failure with preserved ejection fraction with the W-Wave device. J Am Coll Cardiol Cardiovasc Interv. 2015;8(6):870-872.

40. Hasenfuss G, Hayward C, Burkhoff D, et al. A transcatheter intracardiac shunt device for heart failure with preserved ejection fraction (REDUCE LAP-HF): a multicentre, open-label, single-arm, phase 1 trial. Lancet. 2016;387:1298-1304.

41. Kaye DM, Hasenfuss G, Neuzil P, et al. One-year outcomes after transcatheter insertion of an interatrial shunt device for the management of heart failure with preserved ejection fraction. Circ Heart Fail. 2016;9(12):e003662.

42. US National Institutes of Health. ClinicalTrials.gov. REducing Lung Congestion Symptoms Using thE V-wavE Shunt in Advanced Heart Failure (RELIEVE-HF). Available from: https://clinicaltrials.gov/ct2/ show/NCT02511912. Accessed February 13, 2017.

43. Drazner MH, Velez-Martinez M, Ayers CR, et al. Relationship of right- to left-sided ventricular filling pressures in advanced heart failure: insights from the ESCAPE trial. Circ Heart Fail. 2013;6(2): 264-270.

44. Raphael C, Briscoe C, Davies J, et al. Limitations of the New York Heart Association functional classification system and self-reported walking distances in chronic heart failure. Heart. 2007;93:476e82.

45. Goldman L, Hashimoto B, Cook EF, Loscalzo A. Comparative reproducibility and validity of systems for assessing cardiovascular functional class: advantages of a new specific activity scale. Circulation. $1981 ; 64: 1227 \mathrm{e} 34$

46. Wu G, Sanderson B, Bittner V. The 6-minute walk test: how important is the learning effect? Am Heart J. 2003;146(1):129-133.

47. Lam CSP, Roger VL, Rodeheffer RJ, Borlaug BA, Enders FT, Redfield MM. Pulmonary hypertension in heart failure with preserved ejection fraction: a community-based study. J Am Coll Cardiol. 2009;53(13):1119-1126. 
48. Yip GW, Wang M, Wang T, et al. The Hong Kong diastolic heart failure study: a randomised controlled trial of diuretics, irbesartan and ramipril on quality of life, exercise capacity, left ventricular global and regional function in heart failure with a normal ejection fraction. Heart. 2008;94(5):573-580.

49. Hancock HC, Close H, Mason JM, et al. High prevalence of undetected heart failure in long-term care residents: findings from the Heart Failure in Care Homes (HFinCH) study. Eur J Heart Fail. 2013;15: $158-165$.

50. Redfield MM, Jacobsen SJ, Burnett JC Jr, Mahoney DW, Bailey KR, Rodeheffer RJ. Burden of systolic and diastolic ventricular dysfunction in the community: appreciating the scope of the heart failure epidemic. JAMA. 2003;289(2):194-202.

51. van Riet EE, Hoes AW, Limburg A, Landman MA, van der Hoeven H, Rutten FH. Prevalence of unrecognized heart failure in older persons with shortness of breath on exertion. Eur J Heart Fail. 2014;16(7):772-777.

52. Kirk V, Bay M, Parner J, et al. N-terminal proBNP and mortality in hospitalized patients with heart failure and preserved vs reduced systolic function: data from the prospective Copenhagen Hospital Heart Failure Study (CHHF). Eur J Heart Fail. 2004;6:335e41.

53. O'Donoghue M, Chen A, Baggish AL, et al. The effects of ejection fraction on $\mathrm{N}$ terminal ProBNP and BNP levels in patients with acute CHF: analysis from the ProBNP Investigation of Dyspnea in the Emergency Department (PRIDE) Study. J Card Fail. 2005;11:S9e14.

54. Ponikowski P, Voors AA, Anker SD, et al. 2016 ESC Guidelines for the diagnosis and treatment of acute and chronic heart failure. Eur J Heart Fail. 2016;18:891-975.

55. Paulus WJ, Tschope C, Sanderson JE, et al. How to diagnose diastolic heart failure: a consensus statement on the diagnosis of heart failure with normal left ventricular ejection fraction by the Heart Failure and Echocardiography Associations of the European Society of Cardiology. Eur Heart J. 2007;28:2539-2550.

56. Baumgartner H, Bonhoeffer P, De Groot NM, et al. ESC guidelines for the management of grown-up congenital heart disease (new version 2010). Eur Heart J. 2010;31(23):2915-2957.
57. Murphy JG, Gersh BJ, McGoon MD, et al. Long-term outcome after surgical repair of isolated atrial septal defect. Follow-up at 27 to 32 years. N Engl J Med. 1990;323(24):1645-1650.

58. John Sutton MG, Tajik AJ, McGoon DC. Atrial septal defect in patients ages 60 years or older: operative results and long-term postoperative follow-up. Circulation. 1981;64:402-409.

59. Webb G, Gatzoulis MA. Atrial septal defects in the adult: recent progress and overview. Circulation. 2006;114(15):1645-1653.

60. Roos-Hesselink JW, Meijboom FJ, Spitaels SE, et al. Excellent survival and low incidence of arrhythmias, stroke and heart failure long-term after surgical ASD closure at young age. A prospective follow-up study of 21-33 years. Eur Heart J. 2003;24(2):190-197.

61. Duffels MG, Engelfriet PM, Berger RM, et al. Pulmonary arterial hypertension in congenital heart disease: an epidemiologic perspective from a Dutch registry. Int J Cardiol. 2007;120(2):198-204.

62. Lowe BS, Therrien J, Ionescu-Ittu R, et al. Diagnosis of pulmonary hypertension in the congenital heart disease adult population impact on outcomes. J Am Coll Cardiol. 2011;58(5):538-546.

63. Steele PM, Fuster V, Cohen M, et al. Isolated atrial septal defect with pulmonary vascular obstructive disease-long-term follow-up and prediction of outcome after surgical correction. Circulation . 1987;76(5):1037-1042.

64. Brandenburg RO Jr, Holmes DR Jr, Brandenburg RO, McGoon DC. Clinical follow-up study of paroxysmal supraventricular tachyarrhythmias after operative repair of a secundum type atrial septal defect in adults. Am J Cardiol. 1983;51:273-276.

65. Leier CV, Meacham JA, Schaal SF. Prolonged atrial conduction: a major predisposing factor for the development of atrial flutter. Circulation. 1978;57:213-216.

66. Sedgwick P. The Hawthorne effect. BMJ. 2011;344:d8262.

67. Myers MG, Wijeysundera HC. Renal nerve denervation--a hypertension bubble? J Clin Hypertens. 2014;16(7):472-474.

68. US National Institutes of Health. ClinicalTrials.gov. A Study to Evaluate the Corvia Medical, Inc. IASD ${ }^{\circledR}$ System II to REDUCE Elevated Left Atrial Pressure in Patients With Heart Failure With Reduced Ejection Fraction. (REDUCE LAP-HFREF). Available from: https://clinicaltrials. gov/ct2/show/NCT03093961. Accessed February 13, 2017.
Medical Devices: Evidence and Research

\section{Publish your work in this journal}

Medical Devices: Evidence and Research is an international, peerreviewed, open access journal that focuses on the evidence, technology, research, and expert opinion supporting the use and application of medical devices in the diagnosis, monitoring, treatment and management of clinical conditions and physiological processes. The identification of novel

\section{Dovepress}

devices and optimal use of existing devices which will lead to improved clinical outcomes and more effective patient management and safety is a key feature. The manuscript management system is completely online and includes a quick and fair peer-review system. Visit http://www. dovepress.com/testimonials.php to read real quotes from authors. 